doi: https://doi.org/10.15407/microbiolj80.05.003

UDC 579.84+57.063-065.

\title{
MICROBIAL COMMUNITIES AND SULFATE- REDUCING BACTERIA IN SOILS NEAR MAIN-GAS PIPELINE
}

\author{
Abdulina D.R., Purish L.M., Iutynska G.O. \\ D.K. Zabolotny Institute of Microbiology and Virology of the NAS of Ukraine, \\ Zabolotnogo Str., 154 Kyiv, 03143, Ukraine \\ adara@ukr.net
}

\begin{abstract}
Aim of the study: to study the microbial communities and sulfate-reducing bacteria of soils collected from the surfaces of the gas-pipeline. Methods: microbiological, biochemical, molecular biological. Results: In the microbial communities of soils near the main-gas pipeline "Soyuz" (Ivano-Frankivsk region, Ukraine) were appeared such microorganisms as iron-reducing, tionic denitrifying, ammonifying, denitrifying and diazotrophic bacteria among them were dominated sulfate-reducing bacteria. It were obtained 4 pure cultures of the sulfate-reducing bacteria and was determined culturalmorphological and physiological-biochemical characteristics of bacteria. In the fatty acid components of sulfate-reducing bacteria were identified 14 fatty acids with chain length from C10 to C18. According to partial sequence of the 16S rRNA gene the K1 isolate has $90 \%$ homology with the sequence of Desulfovibrio desulfuricans ATCC 27774 (NR074858.1), K2 isolate - 92\% homology with Desulfovibrio sp. D4 (AF192155) K1/3 isolate has 95\% homology with Desulfotomaculum kuznetsovii DSM 6115 (CP002770.1). Conclusion: According to the phenotypic, chemotaxonomic and molecular genetic characteristics bacteria isolated from soils near main-gas pipeline were related to the genera Desulfovibrio, Desulfotomaculum.
\end{abstract}

Key words: sulfate-reducing bacteria, taxonomy, identification, fatty acid composition, $16 S$ rRNA analysis.

Introduction. Sulfidogenic microbial community with major sulfatereducing bacteria $(\mathrm{SRB})$ are present in various natural and man-caused ecotopes, in particular, underground formation and [15], high temperature oil and gas reservoirs, underground storage tanks, oil tankers and communications oil-producing plants $[7,9,22]$; water and soils contaminated with heavy metal salts [11]; water ecotopes such as hypersaline alkaline lakes [21], water distribution and cooling systems, mine waters [4] etc.

Main oil and gas pipelines are one of the most important industrial technological systems. They lay in soil with different composition and physical chemical properties and regions with various climatic conditions. Wide environmental studies [2] had found that the most intense underground corrosive processes were observed in clay soils with neutral $\mathrm{pH}$ and low redox potential. Under such environmental conditions corrosion failures in 50-80\% of cases associated with the activities of SRB. Bacteria produce corrosiverelevant metabolites such as hydrogen sulfide and sulfides, which may result in occurrence of dangerous accidents and failures at mentioned above facilities. 
Recently actual question is the isolation and determination of the taxonomic composition of corrosive-relevant microbial cenosis involved in corrosion processes occurring in the soils surrounding various underground structures.

Therefore, the aim of our study were the isolation, identification and determination of taxonomic position of sulfate-reducing bacteria from corrosive-relevant sulfidogenic microbial communities of the soils near surface main gas-pipeline with using the complex of phenotypic, chemotaxonomic and phylogenetic characteristics.

Materials and methods. Soil sampling. It were sampled and analysed soils taken in 2 different spots near the surface of main gas-pipeline "Soyuz" (Ivano-Frankivsk region, Ukraine). Soil sampling was carried out during the excavation the pipeline in spring-summer season, temperatures during sampling ranged from $8-12^{\circ} \mathrm{C}$ to $25-32^{\circ} \mathrm{C}$. Prior to analysis soil samples were stored in sterile container at $+4^{\circ} \mathrm{C}$.

Microbiological analysis. Determination the amount of main ecological physiological bacterial groups of sulfidogenic microbial communities from soils were carried out by cultivation the series of dilutions in elective liquid nutrient media. Sulfate-reducing bacteria (SRB) were cultivated in Postgate's "B" medium, iron-reducing bacteria (IRB) - in Kalinenko's medium, thionic bacteria (TB) - in Bejeriink's medium, ammonifying bacteria (AB) - in nutrient broth, denitrifying bacteria (DNB) in Giltay's medium, diazotrophic bacteria (DB) - in Vinogradsky's medium $[14,18]$. Bacteria were cultivated at $28^{\circ} \mathrm{C}$ during 5-14 days depending on the group of bacteria. The numbers of bacteria per gram of dry soil were determined according to MacCredy tables [19].

Morphological studies of bacteria were performed using light microscope Meji HT5100 (Japan) (magnification x1000) and transmission electron microscope JEM 1400 (JEOL, Japan). The samples were viewed with the general voltage $80 \mathrm{~V}$ and total instrumental magnification $\times 3000-15000$ times. The measurement of the bacterial cell's sizes on the obtained images were provided with Image J ver.1.43u software program (http://rsb.info.nih.gov/ij/).

Pure cultures isolation. The isolation of SRB pure cultures were performed with using the modified Sturm method on the agar Postgate " $\mathrm{B}$ " and " $\mathrm{C}$ " media [18]. Bacterial cultures were growth in anaerobic conditions at $5-42^{\circ} \mathrm{C}$ using Genbox Jar 7.0 L with oxygen absorbing generators (Biomerieux, France).

Studies of physiological and biochemical characteristics were determined by the ability of bacteria to use different carbon sources (as an electron donor and carbon source - alcohols were added to the medium at a concentration of $1.0 \mathrm{~g} / 1$, organic acids $2.0 \mathrm{~g} / 1$, amino acid $3.5 \mathrm{~g} / \mathrm{l}$ ) and different electron acceptors (sulfate, sulfite, thiosulfate, elemental sulfur). [3, 14, 19, 20].The ability of bacteria to grow and survive with different sodium chloride concentration was determined in the Postgate " $\mathrm{B}$ " nutrient medium with the concentration of $\mathrm{NaCl}$ from 1 to $10 \%$.

Molecular genetic identification. For DNA extraction was used 3-7 days old SRB cultures. DNA from the bacterial biomass was isolated by using reagent kit "DNA-Sorb-B" (AmpliSens, Russia) according to the manufacturer's protocol.

Amplification of $16 \mathrm{~S}$ rRNA gene was performed using universal primer pairs: forward RNNF1 5'-CGGCCCAGACTCCTACGGGAGGCAGCA-3' 
(corresponding to 310-340 pairs of nucleotides of E. coli 16S rRNA gene) and reverse RNN1 5'-GCGTGGACTACCAGGGTATCTAATCC-3/ (corresponding to 770-740 pairs of nucleotides of $E$. coli $16 \mathrm{~S}$ rRNA gene) (http://lyco.lycoming. edu/ newman/) by the PCR running on the 2720 "Thermal Cycler" (Applied Biosystems).The temperature of amplification: initial denaturation $\left(94{ }^{\circ} \mathrm{C}\right.$, $5 \mathrm{~min})$, denaturation 35 cycles: $\left(94^{\circ} \mathrm{C}, 30 \mathrm{~s}\right)$, primer elongation $\left(55^{\circ} \mathrm{C}, 30 \mathrm{~s}\right)$, polymerization $\left(72^{\circ} \mathrm{C}, 30 \mathrm{~s}\right)$ and final cooling to $4^{\circ} \mathrm{C}$. Analysis of PCR products was performed using electrophoresis in 1\% agarose gel stained with ethidium bromide (in concentration $1 \mu \mathrm{l} / \mathrm{ml}$ ) at voltage field $10 \mathrm{~V} / \mathrm{cm}$. Molecular DNA rullers were MassRuller DNA Ladder Mix SM 0403 (Fermentas, Lithuania). Sequencing of $16 \mathrm{~S}$ rRNA genes were carried out according to standard protocol using an automated analyzer "3130 Genetic Analyzer" (Applied Biosystems) using reagent kit "BigDye Terminator v. 3.1 Cycle Sequencing Kit" (Applied Biosystems). The nBLAST program assosiated with GenBank database were used for the searching and comparing homologous nucleotide sequences of genes encoding the ribosomal subunit 16S rRNA (http://www.ncbi.nlm.nih.gov/nblast).

Determination of fatty acid composition. To determine the fatty acid composition of cell lipids were used biomass of 7-10 days old SRB cultures. Bacterial biomass were obtained by centrifuging $40-50 \mathrm{ml}$ of culture liquid in the Eppendorf centrifuge (5415R rotor) at $8000 \mathrm{rpm}$ for $20 \mathrm{~min}$. Biomass twice washed with $30 \mathrm{ml}$ of phosphate buffer $(\mathrm{pH} 7.6)$ from the residues of the cultural fluid and further washed by $5 \%$ sodium citrate solution to dissolve the ferric sulphides compounds.

The methanolysis was carried out with adding to the bacterial biomass $5 \mathrm{ml}$ of a mixture of methanol in $1.0 \% \mathrm{H}_{2} \mathrm{SO}_{4}$ solution. The mixtures were stirred and transferred to the glass ampoules, sealed and carried out the in $80^{\circ} \mathrm{C}$, lasting 4 hours. After the ampoules was opened and added $2 \mathrm{ml}$ of distilled water. Fatty acids extraction was carried out with a mixture of diethyl ether and hexane in a ratio of $1: 1$. The procedure of extraction was carried out three times. The extracts were evaporated at $40^{\circ} \mathrm{C}$ and to the dry extracts were added $0.5 \mathrm{ml}$ of hexane [25]. Analysis of the fatty acids composition was performed on gas chromatograph $6890 \mathrm{~N}$ with capillary column HP-5 MS in 5\% solution of fenylmethyl oxane (column size $30 \mathrm{~m} \times 0.25 \mathrm{~mm} \times 0.25 \mu \mathrm{m}$ ) at $150-210^{\circ} \mathrm{C}$ $\left(4^{\circ} \mathrm{C} / \mathrm{min}\right)$, gas-carrier was helium, flow rate $1 \mathrm{ml} / \mathrm{min}$. To detect the eluents were used mass-spectrometric detector 5973 inert ("Agilent Technologies", USA).

Test-cultures. As bacterial test-cultures for identification the isolates of SRB were used SRB strains from the Ukrainian Collection of Microorganisms: Desulfovibrio desulfuricans UCM B-11501 (DSM642), Desulfovibrio vulgaris UCM B-11502 (DSM644), Desulfovibrio sp. UCM B-11503 (10) Desulfovibrio sp. UCM B-11504 (TC2).

Statistical data processing was performed with the MS Exel 2010 software. Repeated the experiments were three times. The unsaturation degrees were calculated by the formula specified in [10].

Results. Previously we have conducted microbiological studies of the sulfidogenic microbial communities from various man-caused ecotopes with different technogenic load [1]. According to our microbiological analysis of soil samples K1, K2, collected in different spots from surface near the 
main gas-pipeline "Soyuz" were identified the representatives of ecological physiological bacterial groups of the sulfidogenic microbial community. The major group among them were sulfate-reducing bacteria, they appeared in the range from $10^{7}$ to $10^{9}$ cells/per soil $\mathrm{g}$ (Fig. 1).

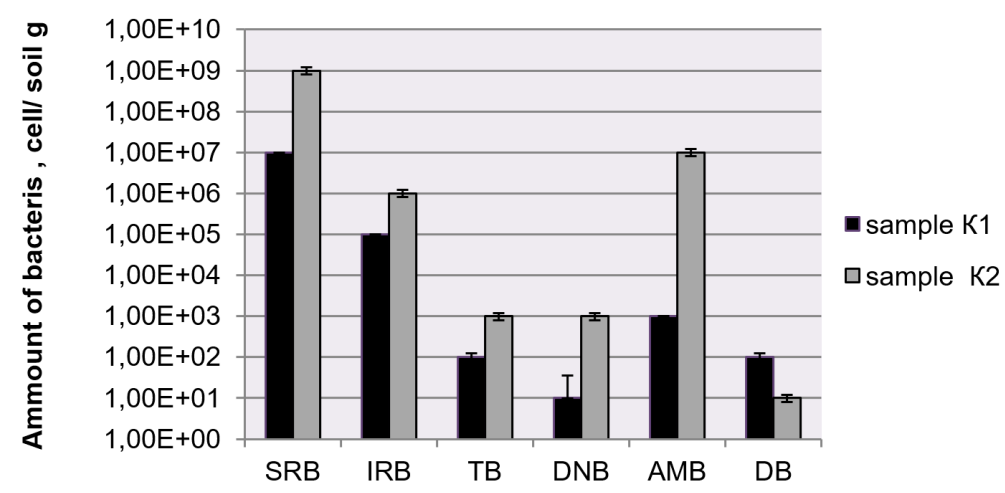

Figure 1. Compound of microbial communities in soils near gas-pipeline "Souyz" (Ivano-Frankivsk region, Ukraine)

Notes: bacteria group - SRB - sulfate-reducing, IRB - iron-reducing, TB - acidophilic tionic, DNB - denitrifying, AMB - amonifying, DB - diazotrophic

Determination of other ecological groups of microorganisms included in the soil microbial communities show that iron-reducing bacteria (IRB) were appeared in amount $10^{5}-10^{6}$ cells/soil $g$ and ammonifying bacteria (AB) $10^{3}-$ $10^{7}$ cells/soil g. Tionic, denitrifying and diazotrophic bacteria were calculated in small amounts $10^{1}-10^{3}$ cells/soil g.

To characterize the soil sulfidogenic microbial communities it is also necessary to study the species and taxonomic composition of the dominant members. Therefore, from the studied soil samples collected from main gas pipeline we isolated and obtained 4 pure cultures of SRB.

The study of bacterial isolates morphology (Fig. 2) showed that the bacterial isolate $\mathrm{K} 1$ has the form of straight rods, sometimes slightly curved, K1/3 isolate cells were vibrio shape. Cells of K2 and K2/3 isolates were characterized by a rod-shaped form, sometimes paired. All SRB were mobile due to lophotrich located flagella, cells were non-spore forming except K1/3 isolate, which formed terminal located spores.

Physiological and biochemical characteristics of sulfate-reducing bacteria are presented in table 1.

SRB isolates were halotolerant, $\mathrm{K} 1, \mathrm{~K} 2 / 3$ isolates were grown at a concentration of sodium chloride from 1 to $5 \%$, and $\mathrm{K} 1 / 3, \mathrm{~K} 2$ isolates at $3 \%$. The bacteria were mesophilic, grown at a temperature range from 20 to $42^{\circ} \mathrm{C}$ and did not grown and showed no activity at $5^{\circ} \mathrm{C}$. As electron acceptors all the bacterial isolates were used sulfates, thiosulfate, sulfites, also were able to use nitrate (except K2/3 isolate); elemental sulfur were used only by $\mathrm{K} 1$ isolate. As carbon sources, in particular organic alcohols and acids, all the studied SRB isolates were used lactate, pyruvate, ethanol, butanol, methanol, succinate, citrate, fumarate (except K2/3), benzoate (except K2, K2/3 isolates), K1, K1/3 isolates grown by consuming acetate. Bacteria are not used the propionate, formate, acetone, butyrate, phenol, oxaloacetic acid (except K2/3) and lactose. 
Isolated SRB were able to assimilate such amino acids as serine, asparagine, arginine, glutamate, asparagine acid and ornithine, not assimilated alanine and glycine. Tryptophan was consumed only by the $\mathrm{K} 2, \mathrm{~K} 2 / 3$ isolates and lysine is not used by K1 isolate.
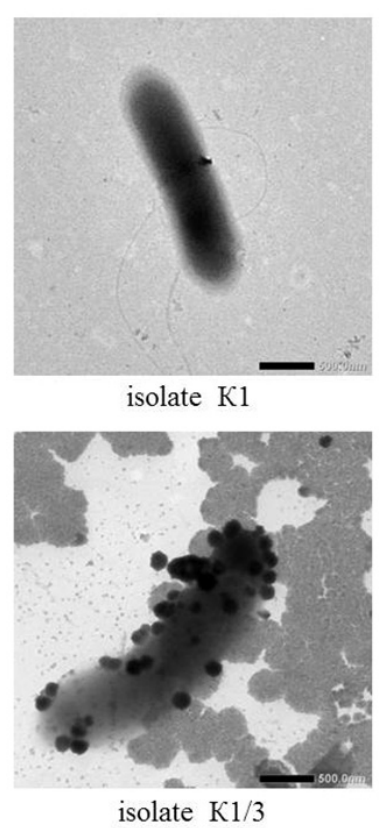

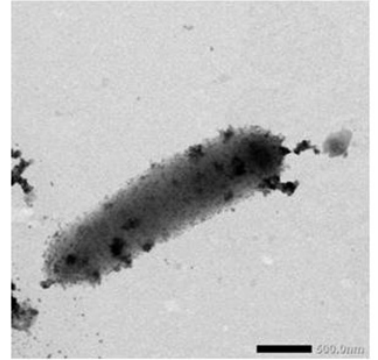

isolate $\mathrm{K} 2$

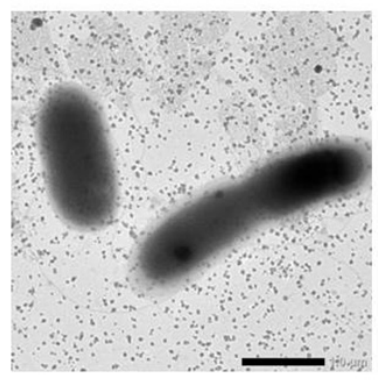

isolate $\mathrm{K} 2 / 3$

Fig. 2. Morphology of SRB's isolated from microbial community, TEM, bar lengths $-500 \mathrm{~nm}$

Chemotaxonomic analysis were conducted and determined the qualitative and quantitative analysis of fatty acid composition of SRB's total lipids and were performed the comparison of fatty acid profiles with the profiles of collection strains Desulfovibrio desulfuricans DSM642, D. vulgaris DSM644, Desulfovibrio sp. 10, Desulfovibrio sp. TC2.

In the fatty acid composition of SRB's cells lipids were identified 14 fatty acids with chain length from $\mathrm{C} 10$ to $\mathrm{C} 18$, among them were saturated tridecanoic (C13:0), tetradecanoic (C14:0), pentadecanoic (C15:0), isopentadecanoic (isoC15:0), antiisopentadecanoic (aiso C15:0), hexadecanoic (C16:0), CIS 9, 10 methylene heptadecanoic $(9,10$ cis $\mathrm{C} 17: 0)$, heptadecanoic $(\mathrm{C} 17: 0)$, octadecenoic (C18:0), hydrooxyoctadecanoic (3OHC18:0) and unsaturated - hexadecenenic (C16:1), transhexadecenic (trans C16:1), cis-octodecenic (cis C18:1) and transoctadecenic (trans C18:1) acids (data shown in table. 2).

In studied bacteria major fatty acids were pentadecanoic (19.91-30.35\%), hexadecanoic (12.91-of 44.66\%) and cis-9 10 methylene hexadecanoic (20.18$23.72 \%$ ). In composition of dominant fatty acids strain K1/3 significantly differed. In its profile is not revealed pentadecanoic and cis- 9,10 methylene hexadecanoic acids and the content of $\mathrm{C} 18$ was the highest (of $44.66 \%$ ) among the analysed bacteria. The degree of unsaturation for $\mathrm{K} 1, \mathrm{~K} 2$ and $\mathrm{K} 2 / 3$ isolates amounted from 0.10 to 0.15 and for $\mathrm{K} 2 / 3$ isolate differed significantly (0.27).

Comparison of fatty acid composition of total lipids of studied bacteria with data obtained from collection SRB cultures showed that K1 isolate was similar 
to Desulfovibrio sp. UCM B-11503 correlation index was 0.96. As well as K1/3 isolate correlated with D. desulfuricans DSM642 and D. vulgaris DSM644 with correlation indexes 0.79 and 0.81 , respectively. This result don't allow us to refer this isolate to Desulfovibrio genus. The $\mathrm{K} 2$ isolate was similar to Desulfovibrio sp. UCM B-11503 with correlation index 0.95.

Table 1

Physiological and biochemical characteristics of SRB from soils near main gas-pipeline

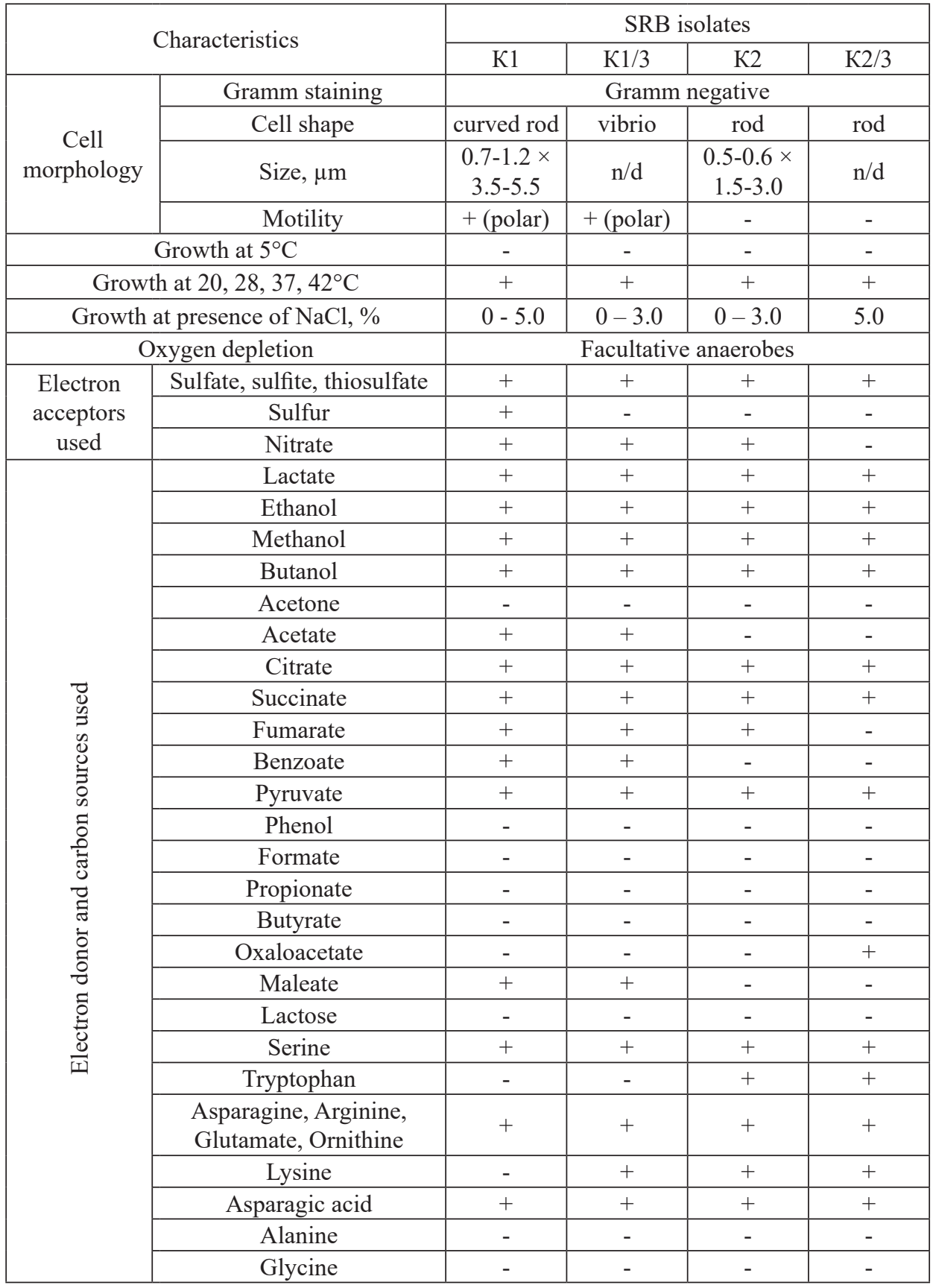

Notes: “+”-presence; “_“- abcense; «n/d»- not determined. 
Fatty acids composition of SRB's cell walls lipids (\% from total amount of fatty acids)

\begin{tabular}{|c|c|c|c|c|c|}
\hline \multirow{2}{*}{ Fatty acid } & \multirow{2}{*}{ Chain length } & \multicolumn{4}{|c|}{ SRB isolates } \\
\hline & & K1 & K1/3 & K2 & $\mathrm{K} 2 / 3$ \\
\hline Tridecanoic & C13:0 & 2.07 & 0 & 1.94 & 1.28 \\
\hline Tetradecanoic & $\mathrm{C} 14: 0$ & 6.42 & 8.69 & 5.22 & 5.56 \\
\hline Pentadecanoic & $\mathrm{C} 15: 0$ & 30.35 & 0 & 19.91 & 23.90 \\
\hline iso-pentadecanoic & iso $\mathrm{C} 15: 0$ & 1.09 & 3.12 & 1.912 & 1.804 \\
\hline Antiiso-pentadecanoic & aiso $\mathrm{C} 15: 0$ & 8.88 & 12.05 & 11.54 & 11.16 \\
\hline Hexadecanoic & C16:0 & 12.91 & 44.66 & 14.37 & 13.88 \\
\hline Hexadecenic & C16:1 & 7.68 & 14.54 & 7.35 & 5.376 \\
\hline Transhexadecenic & Trans C16:1 & 0 & 6.52 & 0 & 0 \\
\hline Cis 9, 10 methylene hexadecanoic & Cis 9,10 C17:0 & 20.18 & 0 & 23.72 & 22.59 \\
\hline Heptadecanoic & $\mathrm{C} 17: 0$ & 3.75 & 0 & 4.16 & 5.08 \\
\hline Octodecanoic & C18:0 & 1.17 & 4.72 & 2.22 & 2.064 \\
\hline 3-hydrooxy octodecanoic & 3OHC18:0 & 0 & 0 & 0 & 2.40 \\
\hline Cis octodecenic & Cis C18:1 & 0 & 2.30 & 1.32 & 1.10 \\
\hline Trans octodecenic & Trans C18:1 & 5.43 & 3.38 & 6.29 & 3.76 \\
\hline \multicolumn{2}{|c|}{ Unsaturation degree } & 0.13 & 0.27 & 0.15 & 0.10 \\
\hline
\end{tabular}

Thus, obtained results of the phenotypic (morphological and physiological biochemical) and chemotaxonomic analysis according to Bergey's Manual of Systematic Bacteriology and Determinative Bacteriology $[5,6]$ allow us to relate to the Desulfovibio genus next bacterial isolates $\mathrm{K} 1, \mathrm{~K} 2, \mathrm{~K} 2 / 3$ and $\mathrm{K} 1 / 3$ isolate was related to Desulfotomaculum genus.

For more accurate species identification of SRB's K1, K1/3, K2 strains were performed the molecular genetic identification by partial sequencing of the 16S rRNA gene sequences. Comparative analysis of the sequences of the 16S rRNA genes were performed using bacterial nucleotide sequences deposited in GenBank database (table. 3).

Table 3 The results of sequence analysis of 16 rRNA gene of SRB strains isolated from soils near main gas-pipeline

\begin{tabular}{|c|c|c|c|}
\hline SRB strain & $\begin{array}{l}\text { Reference strains in GenBank } \\
\text { and accession number }\end{array}$ & $\begin{array}{l}\text { Sequence } \\
\text { length of } \\
16 \mathrm{~S} \text { rRNA } \\
\text { nucleotide }\end{array}$ & Identity, $\%$ \\
\hline \multirow{2}{*}{$\begin{array}{l}\text { Desulfovibrio } \\
\text { sp. K1 }\end{array}$} & $\begin{array}{c}\text { Desulfovibrio desulfuricans strain E0316 } \\
\text { JX267067.1 }\end{array}$ & \multirow{2}{*}{911} & 90 \\
\hline & $\begin{array}{l}\text { Desulfovibrio desulfuricans strain ATCC } \\
27774 \text { NR074858.1 }\end{array}$ & & 90 \\
\hline \multirow{2}{*}{$\begin{array}{l}\text { Desulfotomaculum } \\
\text { sp. K1/3 }\end{array}$} & $\begin{array}{c}\text { Desulfotomaculum kuznetsovii DSM } 6115 \\
\text { CP002770.1 }\end{array}$ & \multirow{2}{*}{480} & 95 \\
\hline & $\begin{array}{l}\text { Desulfotomaculum acetoxidans DSM } 771 \\
\text { CP001720.1 }\end{array}$ & & 91 \\
\hline \multirow{2}{*}{$\begin{array}{l}\text { Desulfovibrio } \\
\text { sp. K2 }\end{array}$} & Desulfovibrio sp. D4 AF192155.1 & \multirow{2}{*}{411} & 92 \\
\hline & Desulfovibrio sp. DSM 2803 AJ251630.1 & & 92 \\
\hline
\end{tabular}


As a result of $16 \mathrm{~S}$ rRNA genes sequence analysis obtained aligned nucleotides with aprox. 400-900 bp were compared with nucleotides deposed in GeneBank database. It was shown that SRB K1 strain has 90\% homology to sequence of Desulfovibrio desulfuricans ATCC 27774 (NR074858.1). K2 strain has 92\% homology to sequence Desulfovibrio sp. D4 (AF192155) (class Deltaproteobacteria, phylum Proteobacteria); and strain K1/3 has 95\% homology to Desulfotomaculum kuznetsovii DSM6115 (CP002770.1) (class Clostridia, phylum Firmicutes). For K2/3 strain analysis was not performed.

Discussion. According to result of phenotypic identification studied SRB strains are related to the Desulfovibrio and Desulfotomaculum genera. Members of the Desulfovibrio genus are not thermotolerance and spore-forming despite the Desulfotomaculum genus. Most related to the Desulfovibrio genus are such SRB genera as Desulfomicrobium, Lawsonia and Bilophila [5, 6].

The results obtained from the fatty acid composition analysis are similar to the data of other researchers [24]. Also, the authors [16] had shown that in many members of the Desulfotomaculum genus was present iso C15:0 fatty acid and it's was identified in small concentrations $(3.12 \%)$ in our studied Desulfotomaculum sp. K1/3 strain. But we need to conclude that fatty acid composition analysis for SRB has low taxonomic resolution.

According to data phylogenetic analysis had revealed more indicative for accurate determination of the taxonomic position of SRB, although the percentage similarity of nucleotide sequences of the 16S rRNA gene for studied strains was $90-95 \%$. Noted that the 16S rRNA gene of SRB strains are characterized by the phenomenon of multicopy and heterogeneity of the terminal insert located at the 5' and 3' terminal regions. The authors [23] had provided the comparative analysis of similar genes in closely related species Desulfotomaculum kuznetsovii and had revealed that the heterogeneity of $16 \mathrm{~S}$ rRNA genes copies distorts the position of bacteria in the phylogenetic tree. SRB are genetically quite heterogeneous group and also has wide range of physiological, adaptive abilities and physiological heterogeneity [26] and because of this SRB can occupy a lot of habitats with various conditions.

Our previously obtained data about the diversity of SRB, isolated and identified by classical microbiological and molecular methods, in such man-caused ecotopes as communications of heating systems [20] and corrosion products of reinforced concrete structures of the DniproHES [3] has shown that the Desulfovibrio, Desulfotomaculum genera are the most common among corrosive relevant SRB. Data from our studies also confirmed by a number of foreign author's studies, which showed a low generic diversity of cultivated $\mathrm{SRB}$ isolated from man-caused systems regardless of the used methods of identification. For example, Guan et al [9] used metagenomic analysis with subsequent creation clone libraries studied the diversity microbial communities in salt waters corrosive high temperature petrol reservoirs and they had shown that the most frequently identified bacteria were representatives of genera Desulfomicrobium (31.4\% of clones) Desulfovibrio (18.2\%) and Desulfotomaculum (25.0\%). In another study among the SRB strains isolated from biofoulings of the heating systems, and identified according to classical microbiological methods and with the use of sequence analysis of $16 \mathrm{~S}$ rRNA 
gene of bacterial clones, SRB were related to the species Desulfovibrio africanus, Desulfotomaculum ruminis and D. putei [12].

Limitations of the microbiological cultural methods lays in the fact that they allows identified in pure cultures less than $0.1-1.0 \%$ of the total amount of the microbial community $[13,17]$. This is not allows to describe the existing bacterial diversity regardless of the microbial community allocation. However, even with the appearance of the modern molecular methods, such as pyrosequencing, the conducted analysis of microbial communities, collected from bottom sludge of lake Sulfatnoe revealed among the Proteobacteria only representatives of the class $\delta$-Proteobacteria $(19.4 \%)$ and among them $87 \%$ of the sequences belonged to the SRB of the orders Desulfobacterales and Desulfuromonadales, only $1.38 \%$ of the identified sequences had a level of homology more than $97 \%$ with known cultivated species SRB such as Desulfuromonas acetexigens, Desulfomicrobium baculatum and Desulfobacterium catecholicum. It is shown low species diversity (only 3 SRB genera) and the number of determined SRB taxons [8].

According to the phenotypic, chemotaxonomic and molecular genetic characteristics bacteria isolated from soils near main gas-pipeline were related to the genera Desulfovibrio, Desulfotomaculum.

Therefore, the combined use of classical cultural and molecular methods can significantly increase the identified bacterial diversity in various mancaused systems, especially in main gas-pipelines. Timely detection of SRB and study of their cultural and physiological biochemical characteristics could help us to develop effective control techniques and protection and prevention methods of pipelines against microbiological corrosion.

\title{
МІКРОБНІ УГРУПОВАННЯ ТА СУЛЬФАТВІДНОВЛЮВАЛЬНІ БАКТЕРІЇ У ГРУНТАХ, ПРИЛЕГЛИХ ДО МАГІСТРАЛЬНОГО ГАЗОПРОВОДУ
}

\author{
Абдуліна Д.Р., Пуріш Л.М., Іутинська Г.О. \\ Інститут мікробіологї і вірусології ім. Д.К. Заболотного НАН Украӥни, \\ Київ, 03143, вул. Заболотного, 154 \\ adara@ukr.net
}

Резюме

Мета роботи: дослідити сульфідогенні мікробні угруповання і сульфатвідновлювальні бактерії із грунтів, прилеглих до поверхні магістрального газопроводу. Методи: мікробіологічні, біохімічні, молекулярно-біологічні. Результати: У мікробних угрупованнях грунтів прилеглих до магістрального газопроводу «Союз» (ІваноФранківська обл. Україна) були виявлені залізовідновлювальні, дентірифікувальні, амоніфікувальні, тіонові та азотфіксувальні бактерії серед яких домінуючими були сульфатвідновлювальні бактерії. Виділено 4 чисті культури сульфатвідновалювальних бактерій та визначено їхні морфолого-культуральні та фізіолого-біохімічні характеристики. У жирнокислотному складі клітин сульфатвідновлювальних бактерій, виявлено 14 жирних кислот з довжиною ланцюга від С10 до С18. За даними часткового секвенування гену $16 S$ рРНК ізолят К1 мав 90\%-у гомологію до послідовності Desulfovibrio desulfuricans ATCC 27774 (R074858.1), ізолят К2 - 92\%-у 
гомологію до Desulfovibrio sp. D4 (AF192155), а ізолят К1/3 - 95\%-у гомологію до Desulfotomaculum kuznetsovii DSM 6115 (СР002770.1). Заключення: За данними фенотипових, хемотаксономічних та молекулярно біологічних характеристик сульфатвідновальні бактерії із грунтів, прилеглих до поверхні магістрального газопроводу, віднесені до родів Desulfovibrio, Desulfotomaculum.

Ключові слова: сульфатвідновлювальні бактерії, таксономія, ідентифікація, жирнокислотний склад, аналіз послідовності $16 S$ рРНК.

\title{
МИКРОБНЫЕ СООБЩЕСТВА И СУЛЬФАТРЕДУЦИРУЮЩИЕ БАКТЕРИИ В ПОЧВАХ, ПРИЛЕГАЮЩИХ К МАГИСТРАЛЬНОМУ ГАЗОПРОВОДУ
}

\author{
Абдулина Д.Р., Пуриш Л.М., Иутинская Г.А. \\ Институт микробиологии и вирусологии им. Д.К. Заболотного НАН Украины, \\ ул Заболотного, 154, Киев, 03143, Украина \\ adara@ukr.net \\ Резюме
}

Цель работы: исследовать микробные сообщества и сульфатредуцирующие бактерии выделенные из грунтов, прилегающих к поверхности магистрального газопровода. Методы: микробиологические, биохимические, молекулярно биологические. Результаты: В микробных сообществах грунтов, прилегающих к магистральному газопроводу «Союз» (Ивано-Франковская обл. Украина), были выявлены железовосстанавливающие, денитрифицирующие, аммонифицирующие, тионовые и диазотрофные бактерии, доминирующими были сульфатредуцирующие бактерии. Выделены 4 чистые культуры сульфатвосстанавливающих бактерий и определены их морфологокультуральные и физиолого-биохимические характеристики. В жирнокислотном составе клеток сульфатредуцирующих бактерий выявлены 14 жирные кислоты с длиной цепи от С10 до С18. По данным частичного секвенирования гена $16 S$ рРНК изолят К1 проявил 90\%-ую гомологию к последовательности штамма Desulfovibrio desulfuricans ATCC 27774 (NR074858.1), изолят К2 - 92\%-ую гомологию со штаммом Desulfovibrio sp. D4 (AF192155), изолят К1/3 - 95\%-ую гомологию к Desulfotomaculum kuznetsovii DSM 6115 (СР002770.1). Заключение: По фенотипическим, хемотаксономическим и молекулярно биологическим характеристикам сульфатредуцирующие бактерии из грунтов, прилегающих к магистральному газопроводу, отнесены к родам Desulfovibrio, Desulfotomaculum.

Ключевые слова: сульфатредуцирующие бактерии, таксономия, идентификация, жирнокислотный состав, анализ $16 S$ рРНК.

1. Abdulina DR, Purish LM, Asaulenko LG, Iutynska GA. [Sulfidogenic microbial communities from technogenically transformed soils] // Mikrobiologyia i biotechnologyia. 2016. 2: 16-29. [Russian]

2. Andreyuk KI, Kozlova IP, Kopteva ZhP, Pilyasheko-Novokhatny AI, Zanina VV, Purish LM. Microbial corrosion of underground structures / Kyiv. Naukova Dumka. 2005. 258 p. [Ukrainian] 
3. Asaulenko LG, Abdulina DR, Purish LM. [Taxonomic position of certain representatives of sulphate-reducing corrosive microbial community] // Mikrobiol. Zhurn. 2010. 72(4): 3-10. [Ukrainian]

4. Bomberg M, Makinen J, Salo M, Arnold M. Microbial community structure and functions in ethanol-fed sulfate removal bioreactors for treatment of mine water // Microorganisms. 2017. 5:61. DOI: 10.3390/microorganisms5030061.

5. Bergey's Manual of Determinative Bacteriology. / In 2 vol. - [transl. from engl.]. [ed. by J.G Holt, N.R. Krieg] Moscow: Mir, 1997. [Russian].

6. Bergey's Manual of Systematic Bacteriology // Second edition, Volume two, Part C, [ed. D Brenner, NR Krieg, JT Staley], New York: Springer, 2005. 1388p.

7. Duncan KE, Gieg LM, Parisi VA, Tanner RS, Tringe SG et al. Biocorrosive thermophilic microbial communities in Alaskian North Slope oil facilities // Environ. Sci. Technol. 2009. 43(20): 7977-7984.

8. Egorova DV. Influence of the ecological conditions on the microbial community diversity of Trans Baikal saline lakes / Thesis Cand Biol. Sci. Ulan-Ude. 2013. 24 p. [Russian]

9. Guan J, Zang BL, Mbadinga SM, Liu JF, Gu JD, Mu BZ. Functional genes (dsr) approach reveals similar sulphidogenic prokaryotes diversity but different structure in saline waters from corroding high temperature petroleum reservoirs // Appl. Microbiol. Biotechnol. 2014. 98: 1871-1882.

10. Guerzoni M, Lanciotti R, Cocconcelli P. Alteration in cellular fatty acid composition as a response to salt, acid, oxidative and thermal stresses in Lactobacillus helveticus // Microbiology. 2001. 147: 2255-2264.

11. Karnachuk OV, Kurochkina SY, Nicomrat D, Frank YA, Ivasenko DA et al. Copper resistance in Desulfovibrio strain R2 // Antonie Van Leuwenhoek. Journal of Microbiology. Holland, 2003. 83: 99-106.

12. Kjeldsen KU, Kjellerup BV, Egli K, Frolund B, Nielsen PH, Ingvorsen K. Phylogenetic and functional diversity of bacteria in biofilms from metal surfaces of an alkaline district heating system // FEMS Microbiol. Ecol. 2007. 61: 384-397.

13. Lakshmi VV. Metagenomics - tool for inexhaustible access to microbial communities. Microbial Diversity Exploration and Bioprospecting. [ed. Ramm Reddy S, Singara Charya MA, Girisham S]. Scientific Publishers (India), New Deli. 2012. Chapter 5: 53-72.

14. Manual of methods for general bacteriology / [editor-in-chief P. Gerhardt]. vol. 1. M: Mir, 1983. 535 p. [Russian].

15. Nazina TN, Rozanova EP, Belyakova EV, Lysenko AM, Tourova TP, Belyaev SS, Poltaraus AB, Osipov GA. Description of "Desulfotomaculum nigrificans subsp. salinus" as a wew species, Desulfotomaculum salinum sp. nov // Microbiology (Mikrobiologiya). 2005. 74(5): 567-574.

16. Nazina TN, Turova TP, Ivanova AE, Belyaev SS, Poltaraus AB, Gryadunov DA, Osipov GA. Phylogenetic position and chemotaxonomic characteristics of the thermophilic sulfate-reducing bacterium Desulfotomaculum kuznetsovii // Microbiology (Mikrobiologiya). 1999. 68(1): 77-84.

17. Parkes RJ Analysis of microbial communities within sediments using biomarkers. In Ecology of microbial communities. Eds: Fletcher M., Gray TR, Jones JG, Cambridge Univ. Press, Cambridge. 1987. 147-177. 
18. Postgate JR. The sulphate-reducing bacteria (2nd ed.). Cambridge: Cambridge Univ. Press, 1984. 208 p.

19. Prakticum po microbiologii (Manual for microbiology) / [ed. by prof. AI. Netrusov]. $\mathrm{M}$ : «Academia», 2005. 608 p. [Russian]

20. Purish LM, Asaulenko LG, Abdulina DR, Iutinskaia GA. [Biodiversity of sulfatereducing bacteria growing on objects of heating systems] // Mikrobiol. Zhurn. 2014. 76(3): 11-17. [Russian]

21. Sorokin DY, Tourova TP, Abbas B, Suhacheva MV, Muyzer G. Desulfonatronovibrio halophilus sp. nov., a novel moderately halophilic sulphate-reducing bacterium from hypersaline chloride-sulfate lakes in Central Asia. Extremophiles. 2012. 16: 411-417.

22. Stevenson BS, Drilling HS, Lawson PA, Duncan KE, Parisi VA et al. Microbial communities in bulk fluids and biofilms of an oil facility have similar composition but different structure // Environ. Microbiol. 2011. 13(4): 1078-1090.

23. Tourova TP, Kuznetzov BB, Novikova EN, Poltaraus AB, Nazina TN. Heterogeneity of the nucleotide sequences of the 16s rRNA genes of the type strain of Desulfotomaculum kuznetsovii // Microbiology (Mikrobiologiya). 2001. 70(6): 788-795.

24. Vainshtein MB, GogotovA GI, Galushko AS. Grouping of sulfate-reducing bacteria by spectral properties of cytochrome c // Microbiology (Mikrobiologiya). 1996. 65(2): 160-164. [Russian]

25. Varbanets LD, Zdorovenko GM, Knirel YuA. Metody issledovania endotoksinov. Kyiv: Naukova Dumka 2006. 238 p. [Russian]

26. Woordow G. The Genus Desulfovibrio: the centennial // Appl. Environ. Microbiol. 1995. 61(8): 2813-2819. 